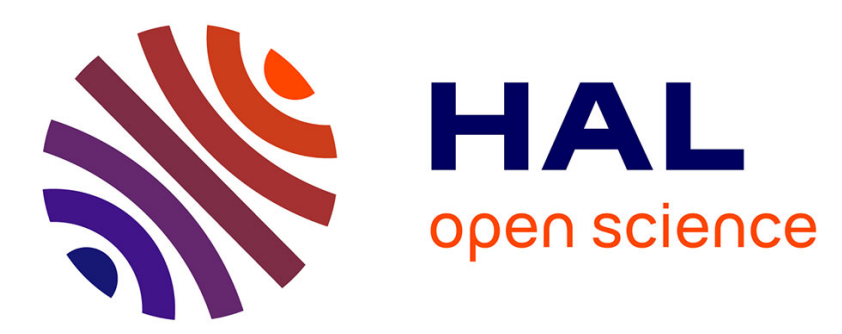

\title{
Transsexualism and transgenderism: Unravelling sex and gender, and abstractions of the sexed body
}

\author{
Jean-Baptiste Marchand, Elise Pelladeau, François Pommier
}

\section{To cite this version:}

Jean-Baptiste Marchand, Elise Pelladeau, François Pommier. Transsexualism and transgenderism: Unravelling sex and gender, and abstractions of the sexed body. International Journal of Psychoanalysis, 2019, 100 (2), pp.206-228. 10.1080/00207578.2019.1589377 . hal-03211691v1

\section{HAL Id: hal-03211691 \\ https://hal.science/hal-03211691v1}

Submitted on 30 Apr 2021 (v1), last revised 30 Apr 2021 (v2)

HAL is a multi-disciplinary open access archive for the deposit and dissemination of scientific research documents, whether they are published or not. The documents may come from teaching and research institutions in France or abroad, or from public or private research centers.
L'archive ouverte pluridisciplinaire HAL, est destinée au dépôt et à la diffusion de documents scientifiques de niveau recherche, publiés ou non, émanant des établissements d'enseignement et de recherche français ou étrangers, des laboratoires publics ou privés. 
Marchand, J.-B., Pelladeau, E., Pommier, F. (2019). Transsexualism and transgenderism : unravelling sex and gender, and abstractions of the sexed body

[Transsexualisme et transgenderism : croisement-décroisement du sexe et du genre, et abstractions du corps sexué]. International Journal of Psychoanalysis, 100(2), 206-228.

Doi: https://doi.org/10.1080/00207578.2019.1589377

\title{
Transsexualism and transgenderism: unravelling sex and gender, and abstractions of the sexed body ${ }^{1}$
}

\author{
Jean-Baptiste Marchand \\ Elise Pelladeau ${ }^{2}$ \\ François Pommier ${ }^{3}$
}

\begin{abstract}
Albeit a relatively old phenomenon, transgenderism currently remains difficult to define and understand due to the fact that it is so polymorphous and changing. Indeed, while it may be considered that in continuity with the mediatization of the transsexual phenomenon and of the first cases of Sex Reassignment Therapy (SRT), the transgender phenomenon appeared in the 1970s with certain cases of secondary transsexualism described by Stoller, and with the "first" transgender person, Virginia Prince (Castel, 2003, p. 486 and 491), it is only recently that the American Psychiatric Association (2013, pp. 451-459) and the $\mathrm{WPATH}^{4}$ (2011, p. 97) have given it a certain recognition in their respective studies.
\end{abstract}

According to the definitions given by these associations of health professionals, transgenderism corresponds first and foremost to a group encompassing all the different forms of gender incongruence (whether or not this incongruence entails distress experienced by the individual, and whether or not there is gender dysphoria). It is "simply" the opposite of cisgenderism ${ }^{5}$, that is, the opposite of the congruence between sex and gender. Thus, according to this broader conception, very diverse issues of identity or of non-conformity of gender may be considered as transgender, such as:

- transsexualism with total hormonal and surgical transformation, but also partial (without an operation of sexual reassignment),

- intersex conditions with ambiguities of genital organs,

- identity-related transvestism,

and even in a certain manner:

- effeminate men who consider themselves as men,

- or virile women who consider themselves as women.

\footnotetext{
1 Maître de Conférences en Psychologie Clinique, Psychopathologie et Psychanalyse, Psychanalyste Psychologue Clinicien. Membre de l'équipe Clinique de l'Acte et PsychoSexualité (CAPS), composante de l'Unité de Recherche multi-sites Recherches en Psychopathologie et Psychanalyse (RPpsy) : Nouveaux symptômes et lien social - UR 4050, Université de Poitiers.

2 Maître de Conférences en Psychologie Clinique, Psychopathologie et Psychanalyse, Psychanalyste Psychologue Clinicien. Membre de l'équipe Clinique de l'Acte et PsychoSexualité (CAPS), composante de l'Unité de Recherche multi-sites Recherches en Psychopathologie et Psychanalyse (RPpsy) : Nouveaux symptômes et lien social - UR 4050, Université de Poitiers.

3 Professeur des universités, Unité de Recherche CLIPSYD EA 4430, Approche Psychopathologie Psychanalytique (A2P), Ecole Doctorale 139 Connaissance, Langage, Modélisation (ED 139), Université Paris Nanterre.

${ }^{4}$ World Professional Association for Transgender Health.

${ }^{5}$ Etymologically, in Latin, while the prefix trans denotes a "crossing", a "beyond" or "the other side", its antonym, cis signifies, on the contrary, "on the same side", "together". Thus according to the American Psychological Association, the term cisgender is "an adjective used to describe a person whose gender identity and gender expression align with sex assigned at birth; a person who is not Transgender and Gender NonConforming People" (APA, 2015).
} 
Marchand, J.-B., Pelladeau, E., Pommier, F. (2019). Transsexualism and transgenderism : unravelling sex and gender, and abstractions of the sexed body [Transsexualisme et transgenderism : croisement-décroisement du sexe et du genre, et abstractions du corps sexué]. International Journal of Psychoanalysis, 100(2), 206-228. Doi: https://doi.org/10.1080/00207578.2019.1589377

Indeed, as the we will show in a more detailed manner in this article, the emergence of transgenderism occurred in part by differentiating itself from transsexualism, not only by contesting the reference to a "medical" term, but also by asserting the right not to be obliged to undergo genital reassignment surgery (GRS). This assertion of a distinction differs from the current proposals in which transgenderism absorbs transsexualism, relegating the latter to a sub-category of gender incongruence. According to this first view, transgenderism and transsexualism each evince a different relationship of the subject to his gender identity, to his sexed body and to the difference between the sexes, a difference that is erased by the current definitions of the APA and of the WPATH (Marchand J.-B. and al., 2015).

Thus, initially this article will present transgenderism as a singular entity, distinct from transsexualism. We will then set out our hypotheses as well as their theoretical framework, namely, that transsexualism and transgenderism correspond in our view to two different types of abstraction of the sexed body, and that their respective transformations relate to an attempt to achieve drive realization through perception as defined by Dejours (2001), which is associated here with a split representation of the difference between the sexes. Finally, before concluding, we will illustrate these theoretical elements with the help of an analysis of two clinical vignettes, those of Claudia and Lucy, two individuals who were transsexual and transgender respectively, whom we met in the context of research work in connection with non-directive clinical interviews as well as with Rorschach testing and Thematic Apperception Test (TAT). Being well aware that transgenderism and transsexualism do not correspond to homogenous and uniform groups of individuals, but rather to different individual pathways (as Lemma, 2013 points out), it is not a matter here - on the basis of only two clinical vignettes - of arriving at generalizable conclusions, but of highlighting the elements of our hypotheses that seemed pertinent for pursuing the study of issues relating to sexed identity and their diversities. Furthermore, the utilization of data arising from projective tests such as Rorschach and the TAT proves interesting here at several levels. First, having been analysed according to the psychoanalytic method of the French projectivist school ${ }^{6}$, this data offers us supplementary psychodynamic material that is complementary to the two clinical research interviews on their own. Moreover, these two tests constitute neutral materials in relation to which good or bad responses are not expected. Their non-directive guidelines invite the subjects to say what the test cards evoke for them, and the analysis of these responses helps to evaluate the subjects' modes of psychic functioning. Finally, in relation to our hypotheses about different types of abstraction and about drive realization through perception of the difference between the sexes, the difference in the materiality of these two tests is particularly interesting here. Indeed, although it is structured around a symmetrical axis, the Rorschach test is nonetheless abstract. It thus faces the subject with an important level of abstraction, which he/she is able to tolerate to a greater or lesser extent. On the other hand, the TAT cards are figurative. They are images whose representation is more or less clear, particularly when they contain characters whose sex and age are clearly determined, which is the case for the "sexed"7 (or "gendered") cards that we have selected here for the data analysis: the so-called BM (Boy/Male) and GF (Girl/Female) cards. In this respect, a subject who is more dependent on perception and/or experiences difficulties faced

\footnotetext{
${ }^{6}$ Initiated among others by Anzieu and Chabert, this school proposes a method for analysing projective tests combining formal and psychoanalytic approaches, which thereby fits into "the framework of psychodynamic clinical psychology while drawing on psychoanalytic theory" (Richelle et al., 2009, p. 8).

${ }^{7}$ See Fig. 1
} 
Marchand, J.-B., Pelladeau, E., Pommier, F. (2019). Transsexualism and transgenderism : unravelling sex and gender, and abstractions of the sexed body

[Transsexualisme et transgenderism : croisement-décroisement du sexe et du genre, et abstractions du corps sexué]. International Journal of Psychoanalysis, 100(2), 206-228. Doi: https://doi.org/10.1080/00207578.2019.1589377

with abstract material, will be better able to (re)organize himself during the TAT than during the Rorschach test.

\section{Transgenderism and transsexualism as abstractions of the difference between the sexes, of gender and of the sexed body}

\subsection{In the beginning, transsexualism}

Attempting to understand historically the birth of the transsexual phenomenon is a more perilous exercise than it might seem. Indeed, it may be considered that the fact that some people feel that they belong to the other sex has always existed, irrespective of the cultures and epochs. It would be fitting then to undertake a rereading of old texts of case studies presenting hypothetically the same conviction of belonging to the other sex as that of transsexual subjects today, going back even to the Middle Ages and earlier epochs.

Another approach consists in referring to the first attempted sex change operations in medicine. Indeed, hormonal and surgical sex reassignment as a medical response to the demand of transsexual patients constituted a major turning-point in the history of transsexualism. Even if this approach tends towards a confusion between transsexualism and SRT (a confusion between the disorder and the treatment), as if transsexualism were an iatrogenic effect of SRT, this approach made it possible to clarify the dates which may be considered as the progressive beginning, if not the emergence and recognition, of the transsexual phenomenon as we know it today. Thus, according to Castel (2003), although in the texts from the seventeenth century we can find cases of transvestism which potentially come within the scope of transsexualism, we can note the following key dates:

- the case of Lucille (Alberta Lucille Hart) who became Alan (Lucill Hart) after a mastectomy, in 1918, [il me semble que la version Wikipaedia est plus logique]

- as well as the first attempts at SRT in Berlin, in the years 1920-1930, directed by Hirschfield, with the case of Rudolf who became Dora, and of Gertrude who became Gert.

At that time, transsexualism was not yet clearly defined and identified. It was still partly confused with homosexuality and transvestism.

The great turning-point that marked the history of transsexualism was most certainly the first SRT considered as complete and successful of George who became Christine Jorgensen, which was made public in December 1952, and which was followed in 1953, by the first official use of the term transsexualism by the endocrinologist, Benjamin, who subsequently defined the term as follows:

True transsexuals feel that they belong to the other sex, they want to be and function as members of the opposite sex, not only to appear as such. For them, their sex organs, the primary (testes) as well as the secondary (penis and others) are disgusting deformities that must be changed by the surgeon's knife... Only because of the recent great advances in endocrinology and surgical techniques has the picture changed.

(Benjamin, 1966, p. 13). 
Marchand, J.-B., Pelladeau, E., Pommier, F. (2019). Transsexualism and transgenderism : unravelling sex and gender, and abstractions of the sexed body

[Transsexualisme et transgenderism : croisement-décroisement du sexe et du genre, et abstractions du corps sexué]. International Journal of Psychoanalysis, 100(2), 206-228.

Doi: https://doi.org/10.1080/00207578.2019.1589377

It is worth underlining the simplicity and clarity of this definition, the three main elements of which are:

- the desire to belong to the other sex;

- the rejection of one's own anatomically sexed body;

- and the wish to modify this body by resorting to SRT to make it conform with the assertion of gender identity.

And even today these are still the three major elements defining transsexualism.

\section{2. ...Then the emergence of transgenderism}

From a historical point of view, the first official use of the term transgenderism dates back to 1979, and is attributed to Virginia Prince (Castel, 2003, p. 491).

Originally, Prince was a heterosexual man who indulged in cross-dressing. After two marriages and two divorces, she chose to live permanently as a woman by resorting to permanent cross-dressing as well as to a feminizing hormonal therapy prescribed by Benjamin. Nonetheless, from the very beginning of her transformation, unlike Benjamin's transsexual patients, Prince claimed that she was not a transsexual person. Latching on to the distinction between sex and gender made by Money et al. (1955): "By the term, gender role, we mean all those things that a person says or does to disclose himself or herself as having the status of boy or man, girl or woman, respectively" (p. 285), she opposed these concepts and asserted clearly and precisely that she did not want to change her sex, but her gender. According to her, her recourse to cross-dressing and her partial transformation through hormone replacement were aimed at changing her gender role, at having the experience, at expressing and/or acquiring a female identity, which she distinguished from the conviction of transsexual patients that they belong to the other sex, and from the other forms of crossdressing associated with an erotic scenario. Thus, for Prince, transgenderism was linked to an issue of gender, whereas transsexualism referred to sex and cross-dressing to erotism. In this respect, she publicly asserted the right to change her gender and not her sex, that is to say she was not seeking to obtain and did not want sexual reassignment surgery. She asserted the right to transform her appearance while keeping her genitals intact. Thus, in 1973, during a medical symposium on SRT, in an assertive and somewhat provocative manner, she told the doctors in attendance, "There is not one thing that any doctor or any surgeon at this symposium could possibly do to improve my gender. Any kind of carving that you might do on me might change my sex, but it would not change my gender, because my gender, my self-identity is between my ears, not between my legs." (Prince, 2005, p. 30).

According to this view, transgenderism refers therefore to a very different phenomenon from the other situations of gender incongruence and non-compliance. Transgender people seek a change in their civil status and a partial transformation of their body (hormonal therapy, breast implants, facial surgery, etc.), but they are seen as different from transsexual people because they do not seek a total transformation. Some transgender individuals describe themselves as man or woman even if "they have not changed sex". Others describe themselves as "neither man nor woman" or "both at the same time", or alternatively Man to $\mathrm{X}$ or Woman to $\mathrm{X}$ (to be understood as unknown, indeterminate, 
Marchand, J.-B., Pelladeau, E., Pommier, F. (2019). Transsexualism and transgenderism : unravelling sex and gender, and abstractions of the sexed body [Transsexualisme et transgenderism : croisement-décroisement du sexe et du genre, et abstractions du corps sexué]. International Journal of Psychoanalysis, 100(2), 206-228. Doi: https://doi.org/10.1080/00207578.2019.1589377

unspecified...). They do not reject all the sexual characteristics of their body, in particular, in certain cases, their genital organs; on the contrary, it is not uncommon for them to desire and assert the right to keep this part of their body intact and functional. Thus some male to female $(\mathrm{MtF})$ transgender people refuse to undergo certain demasculinizing hormonal treatments that may result in erectile dysfunction. Likewise, some female to male (FtM) transgender people preserve their capacity to have children, as was the case for the transgender person who is currently the best known and who has the most media coverage, Thomas Beatie: a FtM transgender person nicknamed "The Pregnant Man", who kept his uterus and obtained three artificial inseminations due to the fact that his partner was unable to have a child. Now, it is this non-rejection of the sexual characteristics of the body as a whole which, in our view, establishes a clear distinction between transgenderism and transsexualism since, for their part, the transsexualists reject and wish, on the contrary, to get rid of their sexual characteristics. It is a clinical distinction that is being erased and which disappears in the overly generic definitions proposed by the APA (2013) and the WPATH (2011).

\subsection{Two entities, two abstractions and two realizations of the difference between the sexes}

\subsubsection{Two expressions of the abstraction of the difference between the sexes}

In keeping with their respective etymology, transsexualism refers to a crossing (trans) of the difference between the sexes, from one sex to the other, and transgenderism to a crossing of gender(s). In this respect, through analogy with abstract art, it may be considered that according to the cornerstone that is the difference between the sexes, transgenderism is to transsexualism what lyrical abstraction is to geometrical abstraction, namely, a tendency to oppose (geometric) formalism via the direct expression of the inner world of the individual through a process of deconstruction and beyond this same formalism (of the difference between the sexes, we could add here). Generally speaking, in the arts, abstraction claims to be non figurative, in opposition to representation. In the case of geometrical abstraction, the creative process follows strict geometric formalism. Lines and colours are taken as the structural basis from which the work is constructed. It is a matter of known and recognised geometrical forms (square, circle, triangle, line, angle, etc.). Lyrical abstraction opposes geometrical abstraction by ridding itself of the latter's constructivist character, thereby accentuating the informal character of the work. It claims to be a freer, more spontaneous and intuitive form of expression in the way it uses materials, technique and the process of creation. Rather than offering visual representations of reality, it seeks to produce a sensory experience through gestural and emotional expression which is expressed in an alliance of projections, marks or brushing resulting in works composed according to aesthetic principles. In the same vein, transsexualism may be likened to the geometrical abstraction of the difference between the sexes. Transsexual people insist on the difference between the sexes and uphold it. They seek a sex change by resorting to the most complete transformation possible. Transgenderism, on the other hand, may be said to correspond to a lyrical abstraction of the difference between the sexes, calling into question the latter's immutability, with a desire to change gender and to undergo a partial transformation. Moreover, it is worth noting that the materiality of the two projective tests that we have used - namely, the Rorschach test and the TAT - seems to us to be most interesting, echoing and being in continuity with this line of questioning on the abstract character of the difference between the sexes in these patients: the first is composed of abstract ink marks, while the second, for its part, is figurative. 
Marchand, J.-B., Pelladeau, E., Pommier, F. (2019). Transsexualism and transgenderism : unravelling sex and gender, and abstractions of the sexed body [Transsexualisme et transgenderism : croisement-décroisement du sexe et du genre, et abstractions du corps sexué]. International Journal of Psychoanalysis, 100(2), 206-228.

Doi: https://doi.org/10.1080/00207578.2019.1589377

\subsubsection{Whole or partial body transformations as drive realizations through perception}

In a certain continuity but above all in complementarity with Lemma (2013), for whom the bodily transformation of these patients is part of a quest for recognition through the gaze of others with the aim of relieving the sense of the gender incongruity at the level of the bodily self (by means of a newly reconstructed body), we contend that these bodily transformations of transsexual and transgender patients correspond to attempts at what Dejours (2001) has conceptualized as a drive realization through perception. According to Dejours, drive realization through perception is aimed at satisfying the sexual death drive (with reference to Laplanche's (1986) conception of it) within a non pathological vicissitude preserving the calm interplay of the preconscious-conscious while reinforcing unconscious splitting. More precisely, Dejours (2001) has conceptualized a third unconscious known as the split unconscious. According to this conceptualization, owing to a demarcation corresponding to a split, the unconscious is composed of two distinct sectors that do not communicate with each other. The split serves precisely to guarantee the simultaneous activity of these two parts, without their knowledge, so that no direct circulation between them is possible. The first part is held to correspond to the "classical" sexual unconscious, the unconscious of the first topography which makes its presence known at the preconscious level by means of returns of the repressed. On the contrary, the other part is different and not related to the sexual and the repressed. It is the replica at the topographical level of the bodily zones excluded from libidinal subversion and thus from the erotogenic body. Within this part there can be neither a return of the repressed nor any thought, hence its designation as "amential". The only modes of reaction to a stimulation of this part would therefore be either the disorganisation of the ego through unbinding and compulsive acting in the form of acts of violence, acting out, somatizations or perversions, or through forms of behaviour and a mode of thinking correctly articulated with reality which differ from the secondary processes governing the preconscious, that is to say, a borrowed impersonal mode of thought, operational and robotic, closely linked to a logical mode of thought resulting from a body of learning, acquired from the outside, and located at the conscious level (logical and not fantasy-based). On this view, the splitting of the unconscious is the result of the intra-topographical separation between two registers, one dominated by the secondary processes, and which is the privileged domain of the sexual life drives, and the other dominated by socio-cognitive processes which give associations an impersonal character, cut off from the unconscious, and which is the privileged domain of the sexual death drive and compulsive activity. We are reminded here of the influence of the retrospective and critical work of Laplanche (1986) on the evolution of the theory of the drives in Freud's work. As a result of this work Laplanche suggested that the biological opposition between the life drives and the death drives should be considered as an error. According to him, and in line with his theory of generalized seduction, the second drive dualism, should be located within an enlarged notion of sexuality which would constitute the only real drive. This opposition could be conceived of, then, as based on a common libidinal energy (a new unified conception of drive energy around the sexual). However, dissymmetry and antagonism would persist, and the opposition between sexual life drives and sexual death drives would correspond more to different modes of energetic functioning. The sexual life drives would function according to the principle of bound energy tending towards a constancy in harmony with the ego, and through the cathexis of a regulating whole object. The sexual death drives would function according to the principle of free energy tending towards zero excitation, in a total drive discharge, potentially more hostile to the ego and at the risk of annihilating the object (reduced to the state of a partial indicator or clue. On the basis of these 
Marchand, J.-B., Pelladeau, E., Pommier, F. (2019). Transsexualism and transgenderism : unravelling sex and gender, and abstractions of the sexed body

[Transsexualisme et transgenderism : croisement-décroisement du sexe et du genre, et abstractions du corps sexué]. International Journal of Psychoanalysis, 100(2), 206-228.

Doi: https://doi.org/10.1080/00207578.2019.1589377

elements, in the case of drive realization through perception, there is no internalized mental representation, and, as its name suggests, the drive satisfaction is obtained through a perception that compensates for a lack of representation, and through a realization that maintains this perception. What is involved, then, is a sort of permanent, but also quiet, acting out in everyday life. It is not a brutal reaction to reality-testing. The subject submits to the pressure from the amential unconscious and intentionally seeks an opportunity for satisfying discharge outside and in reality, in a situation that can potentially give the instinctual impulse the form that it is lacking at the intrapsychic level. It is not sublimation because it is not related to a creative process and a change of aim. On the contrary, the object of the drive realization through perception is not created; it is found by the subject in concrete external reality in order to be accomplished by him and to satisfy the drive. Applied to Dejours' psychodynamics of work, drive realization through perception corresponds to the profession and social status by means of which the subject obtains a secret drive satisfaction in his/her daily reality. By way of example, but without making generalizations or resorting to caricature, consider the former drug addict, who is now abstinent, and works as a representative for a pharmaceutical company, the person who does not want to become an adult and who works in a toy shop, the authoritarian person who works in a public order service, and so on. Thus for transsexual and transgender people, in addition to the issue of being recognised in the eyes of others (Lemma, 2013), it is a matter of realizing and of being able to perceive on a daily basis their gender identity as opposed to their birth-assigned sex through a concrete bodily transformation.

Taking these remarks and hypotheses as our starting-point, and after a succinct presentation of the method of using and analysing Rorschach tests and the TAT according to the French projectivist school, we will attempt to illustrate and analyse the distinction between transsexualism and transgenderism with the help of two clinical vignettes.

\section{Concerning the use of the Rorschach test and of the TAT according to the psychoanalytic method of the French projectivist school: convergences/divergences between the abstract and the figurative.}

\subsection{The Rorschach test}

From a different perspective to that of Exner's perceptual-cognitive approach and his integrated method, the French projectivist school proposes a psychoanalytic interpretation of the Rorschach test based on the qualitative analysis of thought-processes, and of the conflictual and affective dynamics of the narcissistic and object-related axes (Roques, 2014). The Rorschach test is a projective test based on 10 ambiguous, nonfigurative cards. ${ }^{8}$ More precisely, the blot or blots on each card are symmetrical and follow the median axis, which gives this material a structured character, even though it remains abstract. Likewise, according to this psychoanalytic approach and concerning more particularly the theme of our article which is problems of gender identity in transsexual and transgender subjects, the perceptual stimulations induced by the cards infer a reactivation of the latent contents and a resonance at the level of fantasy that can be linked and acquire the value of indicators of identificatory processes (in particular, of the difference between the sexes in terms of phallic-castrated. Thus, generally speaking, through the sexual symbolism, the responses containing protuberant

\footnotetext{
${ }^{8}$ See Fig. 2.
} 
Marchand, J.-B., Pelladeau, E., Pommier, F. (2019). Transsexualism and transgenderism : unravelling sex and gender, and abstractions of the sexed body

[Transsexualisme et transgenderism : croisement-décroisement du sexe et du genre, et abstractions du corps sexué]. International Journal of Psychoanalysis, 100(2), 206-228.

Doi: https://doi.org/10.1080/00207578.2019.1589377

details may be related to phallic symbolisation, whereas recessed or concave details may be said to refer to the symbolisation of the feminine sphere (Moulin, 2010).

\subsection{The Thematic Apperception Test}

Concerning the TAT, the French projectivist school insists on the complementarity of this test with the Rorschach test due to the fact that their clearly distinct materialities allow for the investigation of two different, but inseparable levels of the identity and psychic organisation of the subject (Brelet-Foulard \& Chabert, 2003). The Rorschach test is an abstract structured test in which the symmetrical configuration of blots evokes self/body representations (Chabert, 1983), while the figurative cards of the TAT (notably with figurative representations of people) evoke interpersonal relations. The French projectivist school has thus taken up the TAT, while changing the modalities of testing and analysis of the narratives. Concerning the approaches to analysing the narratives, this school starts from the hypothesis that the elaborative procedures of the discourse refer to unconscious operations of which they are the manifest translation (in particular defence mechanisms associated with the latent evocations of each card, and the unconscious phantasies that it evokes in the subject). The eruption of phantasy is thus evaluated through the gap between the ordinary nature of the theme and the story, as well as by the disturbances in the structuring of the narratives. Furthermore, with regard to testing, the French school only uses 18 cards, 11 of which are offered to all the subjects, and 7 depending on the sex (6 BM and GF cards and the age (one MF card). Given that the object of our study was to investigate issues of gender identity in transsexual and transgender subjects, we offered all the participants the entire set of 18 cards without taking into consideration the recommendation of a different choice of cards for each sex. Thus all the participants were offered the entire set of cards including the masculine BM cards and the feminine GF cards, thereby investigating both masculine and feminine issues (Marchand J.-B., 2016). However, in order to be succinct, we will only present here the narratives of the BM and GF cards.

\section{Context of the interviews and projective testing}

I met Claudia and Lucy in the associative centre where I carried out my research work, and where in parallel I also hold a consultation for people presenting with issues concerning their gender identity. Lucy and Claudia agreed to take part in this research project voluntarily. I saw them for a non-directive clinical research interview, and subsequently they took the Rorschach test and the TAT. They have never been in treatment with us (nor have they had occasional consultations). Similarly, with the aim of avoiding any confusion between the spaces of treatment and investigation, the associative centre, like this research, had no links with the professionals in charge of the SRT.

\section{Claudia: transsexualism and the feminine represented as a container for the geometrical abstract of the sexed body beyond insecurities related to identity and identification}

When she participated in this research, Claudia was about 40 years old. She had finished her SRT and had already enjoyed a change of civil status for several years. Claudia describes herself now as "a woman with a transsexual past", thereby underlining her current status as a woman without, however, denying her past experience. Nonetheless, she told me 
Marchand, J.-B., Pelladeau, E., Pommier, F. (2019). Transsexualism and transgenderism : unravelling sex and gender, and abstractions of the sexed body [Transsexualisme et transgenderism : croisement-décroisement du sexe et du genre, et abstractions du corps sexué]. International Journal of Psychoanalysis, 100(2), 206-228. Doi: https://doi.org/10.1080/00207578.2019.1589377

that her past experience and pathway towards this female identity had not been linear, with regard both to her sense of belonging to the other sex and to her sexual relations or her relationship to her body. Concerning her childhood and her family, Claudia talked about a family setting split according to sex, evoking what Bayle (2012) has theorised around a transmission of a splitting of the parents that may become structural in the child, making this split material unrepresentable (Roussillon, 1999). In her family, Claudia was always with her mother (head of the school where Claudia was educated). Her father did not take care of her and she did nothing with him. On the contrary, her only sister spent all her time with their father and went with him everywhere in all his activities. At this time no one in her family said anything about her already effeminate gender apart from her sister who tried to turn her away from it and to prohibit it, in particular by making fun of, and insulting, Claudia in front of their parents. On the contrary, according to Claudia, her mother frequently made slips of the tongue, calling her by a female first name. Claudia recalled that once when she had forgotten to remove the nail varnish which she put on secretly, her mother had remarked severely: "Be careful that you don't overstep the limits".

Up to the age of 30 , Claudia had seen herself as a homosexual man with a very pronounced feminine side about which she felt very ambivalent. In fact, she rejected it because it evoked in her a sort of internalised homophobia (or transphobia) linked with massive projective impulses: "I didn't like this feminine side of myself. When I saw men in the street who were very feminine, "queers", it made me anxious. I said to myself, My God! I don't want to be like that!" At the same time, it was this feminine side of herself that she liked, unlike the masculine side that she rejected and feared, as much in herself as in others: "I liked everything that was feminine in me ... but everything that was masculine I did not like ... In other words, I loathed everything that was masculine. It reminded me of my condition. [Before], I loathed men. I was afraid of them. Because they would have said, "What's this faggot?" It is as if in addition to a split between the genders feminine/masculine, there was a split between the sexes male/female, and as if no psychic bisexuality (or "bisexuation", as Chiland (2003, p. 49) suggests) was permitted or accessible to Claudia. In the protocol of Claudia's Rorschach, we can see she has a significant difficulty in positioning herself in an identificatory register and avoids the phallic/castrated difference between the sexes that goes with it. In Cards $\mathrm{IV}^{9}$ and $\mathrm{VI}^{10}$ on phallic and bisexual power, the masculine register undergoes a neutralisation-passivation, whereas, as is shown by the response to the female Card VII, ${ }^{11}$ the feminine register can only be cathected timidly and with difficulty: the white space between the blots seems difficult to apprehend. Likewise, in Card $\mathrm{III}^{12}$ on the theme of sexed identification, no sexed polarity can be chosen or envisaged owing to the lack of humanised representation. Finally, the low number of human responses ${ }^{13}$ and the breakdown faced with Card $\mathrm{V}^{\mathbf{1 4}}$ on the theme of identity, where no integrated and unitary response appears, leads us to raise questions about a problem that is both identity-based and identificatory. Faced with this material and its abstract character, Claudia's primary narcissistic foundations prove

\footnotetext{
${ }^{9}$ Card IV: "It's a dead man."

${ }^{10}$ Card VI: "A beaver. There's a crushed beaver ... But the skin... [or perhaps] it's a fox. It's the skin of a fox!"

${ }^{11}$ Card VII: "I can see two characters... It looks like two old women facing each other."

12 Card III: "It's two birds or two monkeys. I don't know."

${ }^{13} \mathrm{H} \%=9.5 \%$, in France, in adults, the norm at $\mathrm{H} \%$ varies between $12 \%$ and $18 \%$.

${ }^{14}$ Card V: "That doesn't mean anything to me ... There are two crocodiles on each side [and] There, there are four mouths" instead of the integrated and unitary responses that are commonplace and frequent: butterfly, bat or flying animal.
} 
Marchand, J.-B., Pelladeau, E., Pommier, F. (2019). Transsexualism and transgenderism : unravelling sex and gender, and abstractions of the sexed body [Transsexualisme et transgenderism : croisement-décroisement du sexe et du genre, et abstractions du corps sexué]. International Journal of Psychoanalysis, 100(2), 206-228. Doi: https://doi.org/10.1080/00207578.2019.1589377

particularly unstable and fragile, with the presence of significant difficulties of selfrepresentation.

Concerning her "conviction" that she belonged to the other sex, Claudia recounted a moment of indecision, when it was above all the status of man that she was rejecting: "I knew that I was not a man, but I didn't know that I was a woman". Similarly, this very conflictual issue related to sex and gender infiltrated her sexual and sentimental relationships, because Claudia said that she was always looking for male partners "officially" leading a heterosexual life in parallel to their homosexual relationship. According to her, it was a question of being desired as a woman, which failed because her partners desired the man that she was. These failures were all the more difficult for Claudia to bear in that they reminded her of her status as a man which she did not accept. Likewise, concerning the sexual act with these men, Claudia told me: "... I had a totally... passive role. I would not have been able to penetrate anyone... It wasn't possible... and it got worse with time. Very quickly, I had quite a feminine position and I didn't really want anyone to touch my genitals...". This position, which Claudia considered as passive and feminine, has echoes with the pair of organisers of psychosexuality, namely, psychic bisexuality and the repudiation of the feminine in both sexes, highlighted by Schaeffer (1997). According to this author, it is by drawing on this pair (psychic) bisexuality/repudiation of the feminine that the lover as a source of jouissance permits - both from the point of view of object-cathexis and from that of identification access to genitality and to the discovery of the vagina as an erotogenic genital zone ("being penetrated" for the woman, and "to penetrate" for the man), thereby going beyond the repudiation of the feminine in both sexes and the negation of the difference between the sexes in association with the two pregenital modalities that are penis envy and anxiety related to passivation/penetration, and thereby creating the feminine. It is a matter of being able to overcome the anxiety connected with penetration in the genital sexual act inasmuch as the latter may have conserved, and be disturbed by, its links with the anal phase, involving negotiation between a reduction of constant tension and repression through a process of rigidification impeding drive introjection at the genital pole (Shaeffer, 1997). With Claudia, this negotiation appears to have failed. The rejection of the masculine and the impossibility of penetrating seem inherent to this solution that is more repressive than based on negotiation, with a repudiation of, and a strict and hermetic closure to, instinctual invasion of the genital zone. Faced with that, an ideal of the feminine woman seems to be the only possibility of an uncontaminated good object that is potentially protective against the aggressive and persecuting bad object that are the masculine gender and the male sex: "... now, I am a woman, I know that they don't feel aggressive towards me”. Before the SRT, Claudia was always in danger of being faced again with this double splitting between sex and gender or of seeing the bad masculine object reappear through the reflection of the good feminine object, like an inverted look-alike; a double splitting that is reminiscent of the particular pseudooedipal configuration described by Donnet and Green (1973), called tri-biangulation, because it is based on a false triangulation and in fact depends on a splitting of the parental imagos. Here, although the difference between the sexes is known, it does not play its structuring role and blurs the oedipal coordinates. It is not the criteria by which the subject identifies the parental objects. The mother and father are differentiated in terms of the characteristic good or bad. The subject is in a relationship with two apparently distinct objects, but which in reality are symmetrically opposable and merge into one. The play of identifications then becomes impossible, culminating in dual relationships. However, although this split could be found again to some extent in the different manner of approaching the sexed cards of the TAT, it 
Marchand, J.-B., Pelladeau, E., Pommier, F. (2019). Transsexualism and transgenderism : unravelling sex and gender, and abstractions of the sexed body [Transsexualisme et transgenderism : croisement-décroisement du sexe et du genre, et abstractions du corps sexué]. International Journal of Psychoanalysis, 100(2), 206-228.

Doi: https://doi.org/10.1080/00207578.2019.1589377

should be noted that unlike the Rorschach test, the figurative quality of this material seems to serve as a support for Claudia in struggling against the underlying aggressiveness. In fact, this aggressiveness remains, but faced with this test, Claudia appears to be able to find the resources to defend herself and to free herself from the latent problem and from its conflictual dimension (which was impossible for her in the Rorschach test), particularly with the female GF cards; it is as if with the TAT, she returned to a problem that was more identificatory than identity-based. Thus in Card $6 \mathrm{BM}^{15}$ on the mother-son relationship, after a sudden and brutal emergence of aggressive feelings, the prohibition of incest is expressed radically by a distancing of the maternal figure who strives to isolate each of the two protagonists, thereby permitting both the renunciation of oedipal loves and the setting aside of conflicts linked to incest and parricide. The maternal figure becomes a governess and the burial becomes an engagement. Similarly, in card $7 \mathrm{BM}^{16}$ on the father-son relationship the rapprochement in an oedipal context, where the difference between the sexes and the generations are clearly established, makes it possible to identify the negative pole of the paternal figure. The father and the son exchange views on their relationships with their women. In Card 6GF ${ }^{17}$ on the phantasy of hysterical seduction, after a libidinalised movement where a negative valency is attributed to the man, the isolation of the woman enables Claudia to attribute the man with an identity of "seducer", and to preserve the innocence of the woman, thereby shedding her phantasy of seduction with too many connotations of incest and seduction. In Card $7 \mathrm{GF}^{18}$ on the mother-daughter relationship, the maternal figure appears in an eroticised coercive relationship which imposes maternity in a superego-like way. But the introduction of a masculine character with a positive valency, who is not present in the image, ("which" removed) has a calming effect on this disorganising phantasy linked to maternity and to mother-daughter closeness, permitting the expression of a desire that is independent of coercion. The girl breaks away from the maternal figure by going towards the man. Finally, in Card $9 \mathrm{GF}^{19}$ on female rivalry the introduction of a masculine figure to whom Claudia attributes this time the role of a bad object underpinned by a phantasy of latent sexual

\footnotetext{
${ }^{15}$ Card 6BM: "To begin with, I saw a funeral. Then, judging by the woman's face, I could see that she was not sad. In fact, It's the man who is in a bit of an anxious state. He has just asked his future parents-in-law for the hand of... his loved one. So, it's the maid who has just announced the arrival of the Gentleman."

${ }^{16}$ Card 7BM: "It's a secret between a father and his son... It's two people who weren't speaking to each other or not much, and then there's the fact that there is a tragic event. [It's] the mother's death, thus the father's wife... Well, the father says to his son... that he regrets perhaps that he wasn't sufficiently loving... [Tells him] not to make the same mistake... The son will listen to his father's advice and in the evening he will tell his wife that he loves her."

${ }^{17}$ Card 6GF: "Why is he leaning over her like that? [She] is surprised... because it's someone she doesn't know ... She doesn't know how to react ... So, after a while, she gets up and moves a bit further away. [It's] an old seducer..."

${ }^{18}$ Card 7GF: "Who is it? It's not her mother... I don't know who it is ... who is telling her to be careful. She has given her a... it's not a baby but a baby doll! The young girl has a baby doll in her arms because it's been imposed on her... Given that it's a girl, she will have children one day ... and in fact, the lady tells her to be careful because [she] is almost going to make him fall over ... But in fact she is not looking at the child at all. That's not what interests her. She's interested in the young man who is passing by. Because she is more attracted by the fact of being a woman ... She will see about being a mother later, but for the time being she needs... love, to seduce... She's not ready yet, but she's being forced to play this role. So I think she is going to give back the doll to the lady and go and say "hello" to the young man."

${ }^{19}$ Card 9GF: "It's the story of a... theft. There's a man who has stolen something... the young girl below was bathing ... and someone arrived... I don't know why I said a man ... but someone arrived, and stole her things, and she cries out 'Stop thief!' ... That's why the lady above comes to see what's going on... And this woman above comes to comfort the girl..."
} 
Marchand, J.-B., Pelladeau, E., Pommier, F. (2019). Transsexualism and transgenderism : unravelling sex and gender, and abstractions of the sexed body [Transsexualisme et transgenderism : croisement-décroisement du sexe et du genre, et abstractions du corps sexué]. International Journal of Psychoanalysis, 100(2), 206-228.

Doi: https://doi.org/10.1080/00207578.2019.1589377

aggression permits the rivalry between women to be turned round into its contrary. The second woman becomes a supportive object when faced with the danger of the bad object. On the other hand, in Card $8 \mathrm{BM}^{20}$ on the parricidal phantasy, particularly aggressive feelings are in the foreground and seem to overwhelm the ego's defences. The story takes a dramatic turn when the father-son relationship is literally transformed into a father-daughter relationship and proves very disorganising, as if linked to a particularly intense emergence of sexual and aggressive drive activity as well as to a significant lack of superego function. The figure in the foreground who is hiding his true sexual identity switches from the identity of a man to that of a girl, and has killed, with complete impunity and without guilt, the man in the background who had discovered the secret of his identity and tried to rape him.

However, concerning her SRT, Claudia told me that when she began it around the age of 30 to 35, she was still not certain that she wanted to go as far as total transformation. She first needed to find out whether her transformation could be credible, to see in society and in her daily life whether the people that she passed in the street "saw" her as a woman (reference to passing and to the need to be seen highlighted by Lemma, 2013). But she was also afraid of losing or of having to abandon all possibility of sexual pleasure, underlining her ambivalence towards it. This ambivalence concerning sexual pleasure appears once again in connection with the sex-gender split described above. Claudia told me that at a certain time after she had undergone vaginoplasty (sexual reassignment surgery), she had a nocturnal orgasm associated with an erotic dream, and that faced with this dream it was the fear of the bad masculine object that reappeared, before it could be soothed by the feminine element: "The first time I had an orgasm as a woman ... I was afraid because it reminded me of the male orgasm. Now, I consider it as very female, and there's no problem." The anxiety aroused by the orgasm associated with a representation of the masculine element seems to return and breach the split, thereby highlighting the traumatic dimension and the failure of the libidinal subversion of this zone of the erotic body the cathexis of which results in drive defusion (Dejours, 2001). It was only by attributing a feminine character to the orgasm that Claudia could contain the overwhelming excitation and the unthought dimension with which it was associated. This brings us back to our hypothesis that, for Claudia, the SRT amounts to drive realization through perception. The aim of this would be to make up for, patch up and sustain the split and impossibility of representation associated with the difference between the sexes and with the threatening masculine element, as well as with the drive excitation of the genital zone, which we can link up with the different level of difficulty of understanding for Claudia between the abstract Rorschach test and the more figurative TAT.

From these diverse elements we can see that Claudia has a need to maintain a strictly split difference between the sexes that is certainly linked to her particular family configuration that is itself split. Calling into question the difference between the sexes brings with it the intolerable risk that the bad masculine object might reappear or contaminate the good feminine object. This is reminiscent of a sort of deficiency at the level of what Laplanche

\footnotetext{
${ }^{20}$ Card 8BM: "It's an autopsy. There are two surgeons who are opening up the body of a man who is dead... as a result of a hunting accident. It's thought to have been a hunting accident but... in fact, it's the... young man in front there who killed him... because the other man had discovered his secret that in fact he is a young woman... The person is very androgynous in the photo and she passes herself off for a man, but in fact she's a woman. And because he discovered this, she killed him to prevent her secret from being revealed... Perhaps he had raped her and so she took her revenge, or perhaps not raped her, but in any case at least he may have tried to rape her... She's going to get away with it because it's going to be considered as a hunting accident."
} 
Marchand, J.-B., Pelladeau, E., Pommier, F. (2019). Transsexualism and transgenderism : unravelling sex and gender, and abstractions of the sexed body

[Transsexualisme et transgenderism : croisement-décroisement du sexe et du genre, et abstractions du corps sexué]. International Journal of Psychoanalysis, 100(2), 206-228.

Doi: https://doi.org/10.1080/00207578.2019.1589377

(2007) theorised concerning an ordered gender-sex/sexual triad linked to generalized seduction. On this view gender is seen as preceding the sexed (phallic/castrated); however, even though it comes second, the sexed organises gender giving it its binary character. Finally, sex and gender, far from being opposed, join forces against the residue of perverse and polymorphous infantile sexuality repressed by the adult that is the sexual, like a process of repression-symbolization.

\section{Lucy: transgenderism, a lyrical abstraction of the sexed body between solid identity and the instability of sexed identifications}

When I met Lucy $^{21}$ for this research interview, she was a young person aged about 30. She told me that she had difficulties in her relationships at work which she thought were due to her appearance - at that moment - of being an effeminate man. Furthermore, during the interview, she said that in these moments that she found difficult she sometimes resorted to consuming an excessive amount of cannabis in order to fight against anxiety and depression.

Concerning the steps she was taking to bring about a transformation of her appearance at the time of this interview, Lucy was pursuing a course that she had begun roughly a year before, with the help of psychotherapy sessions with a psychiatrist in private practice and a prescription for hormonal treatment by an endocrinologist. She said she did not want to have recourse to sex reassignment surgery because, for her, it was of no interest. Indeed, concerning her genital organs, Lucy said:

This part of my body does not pose any problem for me ... I don't want them to touch that. It remains a part of my body with which I can have pleasure, but alone ... I have genitals. I was born with them and they do not disgust me ... I have the impression that some people want [to be operated on] because otherwise you are not a woman if you have a penis between your legs. Having a vagina between your legs does not make you a woman. People don't see what I have got in my knickers ... I think that what is most important is really the visible physical changes ... Because when one is walking in the street, people can't tell the difference.

This is reminiscent of what Green (1973) theorized around a phantasy of a neuter gender as an abolition of the difference between the sexes aimed at denying castration and avoiding the Oedipus complex. Since it is not possible to be a man and a woman, the gender phantasy (neither man nor woman), it is argued, creates an illusion of self-sufficiency with an idealising tendency accompanied by erotic impoverishment. Furthermore, it entails a real crushing of drive activity dominated by absolute primary narcissism that annihilates all desire and all excitation. From this perspective, Lucy's responses to the BM and GF cards of the TAT help us to see that the masculine register provokes in her the eruption of invasive and destructuring pseudo-oedipal unconscious phantasies, whereas the feminine register is cathected along lines of idealization and fetishization which do not allow her to gain access to

\footnotetext{
${ }^{21}$ In this article, we have chosen to use a female first name in spite of appearances. It is a matter here on the one hand of respecting the way in which the person requested to be named, but also of trying to account for the particular encounter which from the outset shakes up (or unsettles) the clinician concerning his relationship to gender and to the difference between the sexes. The clinician may himself find he has a sense of gender disturbance or dissonance, particularly due to the fact that a person presents him/herself to him and that he may have to name this person by a first name that is sexually not in keeping with their appearance.
} 
Marchand, J.-B., Pelladeau, E., Pommier, F. (2019). Transsexualism and transgenderism : unravelling sex and gender, and abstractions of the sexed body [Transsexualisme et transgenderism : croisement-décroisement du sexe et du genre, et abstractions du corps sexué]. International Journal of Psychoanalysis, 100(2), 206-228. Doi: https://doi.org/10.1080/00207578.2019.1589377

a sufficient degree of elaboration that would enable her to overcome the underlying oedipal conflicts. In fact, Lucy's relationship to the feminine register either remains enclosed within a specular-narcissistic relationship (which freezes drive activity) or reminds her of an intolerable relationship of dual rivalry. Concerning the masculine register, in Card $6 \mathrm{BM}^{22}$ on the theme of the mother-son relationship, the absence of a relationship between the two characters gives us a glimpse of Lucy's inability to conflictualize this relationship and to assume the phantasy of incest that goes with it. In Card $7 \mathrm{BM}^{23}$ on the theme of the father-son relationship, a phantasy of homosexual seduction by the father that cannot be elaborated imposes itself in a movement of massive projection that cannot be avoided or contained. For Lucy, Card $8 \mathrm{BM}^{24}$ on parricidal phantasy evokes a confusion of identities and a calling into question of the difference between the sexes. Lucy is unable to attribute a sex to the character in the foreground (apart from a judgement based on an arbitrary detail) and ends up by merging or not differentiating it from the character in the background. Concerning the feminine register, in Card $6 \mathrm{GF},{ }^{25}$ concerning the theme of the phantasy of hysterical seduction, the emergence of oedipal desires transpires in the relationship between the characters, but Lucy is unable to tolerate this underlying charge of phantasy linked with this relationship. The story remains fixed within a descriptive discourse. In Card $7 \mathrm{GF}^{26}$ relating to the mother-daughter relationship, the movements of identification and ambivalence are blocked and femininity, which is transposed on to the mother-daughter relationship, is then caught (bogged down) in a movement of idealization that maintains the difference between the sexes and generations in the desexualized context of a narcissistic relationship. Based on the attribution of a supportive function to the maternal figure, the idealization of the relationship slides towards an objectalization with a narcissistic cathexis of the finery of the daughter who is relegated to the rank of a feminized fetish object. Finally, in Card 9GF, ${ }^{27}$ female rivalry cannot be conflictualized and results in a confusion of identity both in the primary dual relationship and with the subsequent introduction of a third party, and the

\footnotetext{
${ }^{22}$ Card 6BM: "This is a side-view of an old woman, and I would say her son... It's rather solemn... [perhaps] someone has died. They look... sad... The man is not married... The woman's gaze is directed outwards."

${ }^{23}$ Card 7BM: "Two gentlemen who seem quite close... The old man is looking tenderly at the young man [who] is not looking at him, but has an expression of scorn on his face and is not smiling unlike the old man, um... We don't know if it's father and son or a homosexual relationship. In any case, the old man is attracted by the young man."

${ }^{24}$ Card 8BM: “We are witnessing a scene of violence ... we can see two men ... who are stabbing another man. Or the man is perhaps already dead... I don't know... And in the foreground, there is ... a person. I don't know whether it's a young man or a young woman. Quite an androgynous person. Judging by the tie it's a boy but it might be a tomboy... The person is indifferent to the scene. One wonders if it is not the soul of the person who is being attacked."

${ }^{25}$ Card 6GF: "Another scene ... Hollywoodian. There's a woman... very classy who is observing an old man who is behind her ... I don't know if really, if it's a loving relationship or a father-daughter relationship. There's a difference of age ... He seems to be looking at her ... There is no love in his gaze ... or in hers, in fact."

${ }^{26}$ Card 7GF: "It's a young damsel with her mother... who are very well dressed... The mother is reading and the girl... who seems happy but is doing nothing. She has got a little handbag, so she is certainly getting ready to go out... I think that her mother is helping her to get ready, has done her hair, put her clips in her hair so that she can ... perhaps go to church ... Clearly she is not dressed to go out to play. She is smartly dressed."

${ }^{27}$ Card 9GF: "We can see a young girl in a dress... I would not say that she's a young bride...the young girl is on the right. On the left, excuse me! She is running. She seems to be running away and we can see above her a slightly older lady also wearing a dress and who is holding a book in her hand and who also seems to be trying to get away. [Perhaps she] is fleeing because she is disappointed... It's perhaps a married woman. No, it's not a married woman but she had prepared herself to see... her fiancé and perhaps she is running after him or perhaps she is running away."
} 
Marchand, J.-B., Pelladeau, E., Pommier, F. (2019). Transsexualism and transgenderism : unravelling sex and gender, and abstractions of the sexed body

[Transsexualisme et transgenderism : croisement-décroisement du sexe et du genre, et abstractions du corps sexué]. International Journal of Psychoanalysis, 100(2), 206-228.

Doi: https://doi.org/10.1080/00207578.2019.1589377

expression of conflict. The female characters are undifferentiated (or merged) and the story cannot be developed.

Aside from that, notwithstanding her wish to appear as a woman and the hormonal treatment, at the time of the interview Lucy still did not present herself with a feminine appearance. She had still not made her social transition in a permanent way. She only engaged in complete MtF cross-dressing during her "free and personal" time, in certain situations and depending on the context, usually in the evenings and at weekends. In daily life and particularly at work, she maintained a masculine appearance. Her appearance was that of a young man with very pronounced manners and facial expressions. Likewise, concerning her first name, at the associative centre, in keeping with the way in which people are admitted there, she did not give the first name that she was given at birth, and is called by the female first name that she has chosen for herself, namely, "Lucy". Concerning her gender and her identity, she told me that she had always been effeminate and wanted to belong to the other sex. For her, the difference between the sexes appears once again to be split: "Women, it's beauty, kindness, ... Men ... it's disgust." However, her remarks on the links between her effeminate gender, her self-image and her sexed body seem particularly disturbed, as if Lucy was trying to struggle against the presence of drive tension that was potentially disorganising because it was difficult to represent, as if her attempts to rationalize and avoid the conflict were failing on the boundary of emerging primary processes disorganising her discourse:

I lived with my gender whatever it was. It did not cause me any problems. I think that one's gender expression is... In fact, I can't express it ... I have never seen myself as a woman! I am not a man, that's obvious! I'm not a woman either. But on the other hand I refuse to get old as a man. Because it's quite repugnant. Because my body would be too virile and would not correspond to what I am. I want my body to be in line with myself so to speak ... I have always wanted to be a girl. I thought about it and quickly understood that in any case, I was as I was, but that in any case I did not want my body to be that of a man. In fact, I am unable to express my gender with my body ... It was really the bodily modification that... that seemed necessary to me. It's first and foremost a question of the body. As for my gender, well, there you go! I've got the gender that I've got.

Gender, self-image and the sexed body are interwoven here without there being any defence to contain the drive tension associated with them. Gender seems to lack consistency and recalls the difference between the sexes and the sexed body which Lucy tries to deny, thereby failing to support Lucy's splitting of the sexes in association with the phantasy of the neuter gender, a split, on the contrary, that is profoundly damaged. More precisely, concerning this point, Lucy's responses to the Rorschach test suggest that her narcissistic and identity-based foundations are solid and impermeable, and that she has a relatively welladapted grip on reality (more normalized than normal) probably aimed at containing potentially invasive instinctual excitation. Lucy accompanies her responses with remarks to do with "symmetry" and/or "colour", which seem to have the role of containing drive activity and its potentially invasive character; this is particularly observable in the four anatomical ${ }^{28}$

\footnotetext{
${ }^{28}$ Card II: "Red lungs, euh... The image is symmetrical."

And, "a bit like a human body, euh... (an X-ray)",

Card VIII: "The human body, the lungs, the rib cage... with colours"

Card IX: "In the centre, it looks like a brain, the scull. Well, a brain. I don't know... still three colours."
} 
Marchand, J.-B., Pelladeau, E., Pommier, F. (2019). Transsexualism and transgenderism : unravelling sex and gender, and abstractions of the sexed body [Transsexualisme et transgenderism : croisement-décroisement du sexe et du genre, et abstractions du corps sexué]. International Journal of Psychoanalysis, 100(2), 206-228. Doi: https://doi.org/10.1080/00207578.2019.1589377

responses (organs and inside of the body) which are a mark of anxiety. Thus, the primary narcissistic foundations seem solid and impermeable as can be seen from Lucy's responses to the compact cards, ${ }^{29}$ even if her responses are rigid, without movement, as if to avoid putting the solidity of these foundations to the test. On the other hand, the sexed identifications appear to be fragile. Indeed, in card $\mathrm{IV}^{30}$ on the theme of phallic power, the phallic register is recognized and treated in a passive mode to the point of devitalization. This representation and the card are strongly disparaged by Lucy, for whom it is the card she least appreciates. Similarly, in response to the bisexual Card VI, ${ }^{31}$ after a significant period of hesitation, Lucy focuses solely but timidly on the lower feminine part. The upper phallic part elicited no comments. It is only after doing the test that she dares to speak about this upper phallic part, ${ }^{32}$ even if she still continues to protect herself by adding a remark in connection with "symmetry". The feminine register and the disparaged and rejected masculine register which elicits disgust in her, is the mark of the fragile character of her sexed identifications, which stands in contrast with the first impression that she has solid primary narcissistic foundations.

Concerning the evolution of her issues of gender identity as well as the course her life had taken, Lucy told me that until the age of about 25, she had thought of herself as gay. She then had a serious love affair for 5 years with another man. But she gradually began to feel increasingly ill-at-ease in this relationship. During sexual relations, Lucy felt uncomfortable about her penis, refusing to be touched there and refusing to use it. Likewise, Lucy had a growing desire to cross-dress as a woman, which wouldn't have suited her partner. Not being able to tolerate this situation any longer, Lucy put an end to the relationship and, being single once again, she decided to carry out her wish to engage in cross-dressing to the point even of creating a real character for herself, another female identity that she adopted regularly during her free time and on certain other occasions. However, after a period of finding satisfactions in this behaviour that lasted several years, the effects on Lucy of resorting to cross-dressing turned, as it were, into their contrary. While it seemed to satisfy to some extent her desire to see herself as a woman, the cross-dressing left Lucy with a sense of frustration and disgust. Contrary to the feminizing power that she had attributed to it initially, it ended up revealing to her everything that was and remained masculine in her. It underlined "her imperfections", leaving her with the impression of being nothing more than a caricature.

I was always very closed in on myself, very introverted. But I didn't know why. I began cross-dressing ... And then after doing that I found that it was not an end in itself, and that it wasn't what I was looking for, that there was something else ... that was when I realized with my friends that I didn't do it in the same way as they did. It wasn't crossdressing for party purposes ... Now I find that completely stupid. At one point I was also disgusted because I said to myself: "What's this? It's ridiculous!? And it was through cross-dressing that I saw the imperfections, the signs of virility, that were there and disgusted me. And I told myself that it was no longer possible... I was extremely sad. I did not like myself. I couldn't stand myself any more. In the end I was smoking cannabis every evening. I couldn't stand my "body" between inverted commas any longer. It

\footnotetext{
${ }^{29}$ Card I: "A bat, perfectly symmetrical."

Card V: "An insect. There are wings" and "the rear view of a bat."

${ }^{30}$ Card IV: "A dissected animal... with a long tail" and "a hairy animal, rather revolting and not very attractive."

${ }^{31}$ Card VI: “I don't know... there's a ...er... er ... a leaf, again perfectly symmetrical.”

${ }^{32}$ Card VI: "A snake's head"
} 
Marchand, J.-B., Pelladeau, E., Pommier, F. (2019). Transsexualism and transgenderism : unravelling sex and gender, and abstractions of the sexed body

[Transsexualisme et transgenderism : croisement-décroisement du sexe et du genre, et abstractions du corps sexué]. International Journal of Psychoanalysis, 100(2), 206-228.

Doi: https://doi.org/10.1080/00207578.2019.1589377

really had to become more feminine. I think that with age, it was becoming more virile and that's not the image I wanted to give. My hair, which was falling out, reminded me a bit of my mother when she was having her menopause. Losing her hair really affected her.

Similarly, having lived as a gay person, the problems related to her gender identity revealed themselves and became increasingly important. Thus, just as with Claudia, we find in Lucy a strong rejection of the masculine. However, the more or less subtle differences that exist between their respective problems of gender identity need to be underlined. Claudia's difficulties seem to be related more to the great importance that she attributes to the way others perceive her. In particular, it was after experiencing the way others looked at her when she adopted a feminine identity that she decided to ask for sex reassignment surgery. Finally, her issues of gender identity and her transformation seem to be linked to intense and oppressive feelings of fear of the masculine considered as aggressive and threatening. In contrast, Lucy's issues of gender identity seem more related to the representation that she has of herself. Lucy seems to be more in search of a change of appearance (related to her selfimage) than a change of anatomy and of her sexed body as a whole. Moreover, she insists on keeping her penis, even if it is only for her personal pleasure. Thus her issue of gender identity seems more narcissistic, involving autogenyphilic desire (Blanchard, 1989) linked to an idealization of the image of women, combined with a rejection of the masculine register perceived not as threatening but as synonymous with a degradation of her self-image. The masculine register arouses very oppressive feelings in her of self-disgust harking back to a confusion of identities in the relationship with the primary object. Lucy's hair loss is associated directly with the virilisation of her body and considered as identical to her mother's loss of hair during menopause, marking the link between issues of gender identity and issues situated at the level of identification with the primary object. Faced with the latter, the different moments in the course of Lucy's life, that is to say her life as a homosexual couple, her recourse for a certain time to cross-dressing, but also her current transformation or her problems of cannabis consumption, recall what McDougall (1982) conceptualized in connection with a transitory object aimed at compensating for the lack of introjection of the transitional object. It is a matter therefore of finding and recreating the object outside in order to protect oneself from loss and the void. This issue of identification linked to the transition from primary identification to primary homosexuality (Kestemberg, 1999) - the transition from a relationship with the same in primary identification to one with a similar but not identical other (the truly object-related side of this primary identification) permitting the sufficiently solid ego to blossom - seems increasingly intense, and these very same moments and changes in Lucy's life seem to be attempts at drive realization through perception (Dejours, 2001) which failed and were repeated up until the current solution of partial transgender transformation.

\section{Conclusion and discussion}

The cross-investigation of the issues of gender identity in Claudia and Lucy based on clinical interviews and projective tests has made it possible to clarify the particularities and subtleties that differentiate these issues from each other. Beyond a number of similarities in their life trajectories, the respective relations of Lucy and Claudia to the difference between the sexes and to its representations are different. The rejection of the masculine register is 
Marchand, J.-B., Pelladeau, E., Pommier, F. (2019). Transsexualism and transgenderism : unravelling sex and gender, and abstractions of the sexed body

[Transsexualisme et transgenderism : croisement-décroisement du sexe et du genre, et abstractions du corps sexué]. International Journal of Psychoanalysis, 100(2), 206-228.

Doi: https://doi.org/10.1080/00207578.2019.1589377

present in both of them, and seems particularly intense, but while for Claudia it is associated with threatening aggressiveness, for Lucy it is related to the representation of her masculine image which, with age, she loathes more and more, arousing in her a sense of disgust. Likewise, with Claudia, only the feminine and entirely female woman, seems to make the difference between the sexes acceptable beyond the split between the sexes and genders. In this respect, for her, the difference between the sexes must be maintained, in particular by means of the most complete transformation possible of her sexed body which, like drive realization through perception, helps both to support, relieve and make the split less severe. It is as if this realization though perception made it possible both to counterbalance the aggressive and threatening bad masculine object, while keeping the representation of this bad object, which has direct echoes for her with intense issues of identity and identification, outside of herself. In contrast, for Lucy, the image of the feminine woman seems to be related to a narcissistic ideal, opposed to this rejection of the masculine register. To return to the transgender discourse of Prince in 1973, the issue for Lucy is more one of changing gender and appearance than of changing sex. The autogenyphilic desire appears to be correlated with this rejection. In her, the splitting of the sexes seems to be linked to a phantasy of the neuter gender which her (partial) transformation establishes by means of a drive realization through perception with a more narcissistic aim this time. What we have here then is two distinct ways of relating to the difference between the sexes, two different modalities of abstraction of this difference, which reflect the difference between the transsexual (change of sex with complete hormonal and sex reassignment surgery) and transgender (change of gender with partial transformation) phenomena.

Concerning the hypothesis of transformations as a drive realization through perception, the trajectory and realization of the transformation seem to us to pertain to a register with a sexual aim, that of the sexual death drive which is quietly satisfied in daily life through perception. It is a matter of seeking unconscious satisfaction in an object of material reality that is concrete and external to the reconstructed body.

The findings of the projective tests allow us to fine-tune these elements still further. Concerning the issue of gender identity and its relation to the difference between the sexes in Claudia, the Rorschach test showed that Claudia was unable to cathect either the masculine register or the feminine register, and also highlighted significant deficiencies at the level of her primary narcissistic foundations. On the other hand, the analysis of Claudia's responses to the male (BM) and female (GF) cards of the TAT, suggests that she may be able to find suitable ways of coping with the latent stimulations of the male and female issues (if the phantasy aroused is not too aggressive).

For their part, Lucy's responses to the Rorschach test show that her primary narcissistic and identity-related foundations are sufficiently solid and impermeable, even though maintaining these foundations only seems possible on the condition that any instinctual movement that may undermine them can be neutralized. On the other hand, in spite of these foundations of identity, a significant fragility is apparent at the level of sexed identifications. The phallic register is recognized and tackled in a passive mode to the point of devitalization. It is disparaged and elicits rejection and a sense of disgust. For its part, rather surprisingly, the feminine register is only timidly approached and tackled, always under the cover of defences aimed at containing potentially invasive drive movements. This issue of identification - which concerns as much the masculine register as the feminine - is confirmed by the analysis of the responses elicited by the BM and GF cards of the TAT. In the male BM 
Marchand, J.-B., Pelladeau, E., Pommier, F. (2019). Transsexualism and transgenderism : unravelling sex and gender, and abstractions of the sexed body

[Transsexualisme et transgenderism : croisement-décroisement du sexe et du genre, et abstractions du corps sexué]. International Journal of Psychoanalysis, 100(2), 206-228.

Doi: https://doi.org/10.1080/00207578.2019.1589377

cards, the masculine register gives rise to the emergence of pseudo-oedipal phantasies which breach and disorganize Lucy's discourse and narratives. Faced with the female GF Cards, either the feminine register cannot be cathected beyond the level of a specular-narcissistic relationship (operating between idealization and fetishization, freezing the movement of the drives and preventing Lucy from being able to free herself from the underlying oedipal conflicts) or it is rendered impossible by the appearance of an intolerable "feminine" dual rivalry.

The cross-comparison of these elements presents us with multiple paradoxes. With Lucy, the foundations of identity are stable but issues of identification are particularly prominent, both in the Rorschach test and the TAT. In Claudia's case, the foundations of identity are very fragile, while issues of identification also appear at first sight to be significant (especially in the Rorschach test). Nonetheless, concerning these issues of identification in Claudia, a difference may be noted between her difficulties in cathecting the phallic and feminine registers in the Rorschach test, and her easier approach to masculine and feminine issues in the TAT.

Thus, it seems relevant to suggest that there are effects of resonance between the materiality of each of these tests and the respective issues of Lucy and Claudia. They both showed difficulties concerning the phallic and feminine identificatory registers in the Rorschach test, and we would like to suggest that this difficulty may be linked to the particular test object that is the Rorschach test, which, albeit structured, is nonetheless abstract. Concerning the male BM and female GF cards of the TAT, we see no change in Lucy's rejection of the masculine register. On the other hand, with Claudia, we can see that she is able to cope with the latent stimulations of these cards (depending on the intensity of the possible aggressiveness). Furthermore, it should be noted that in Lucy's case the freezing of drive activity in the specular relationship to the female cards of the TAT contrasts with the timidity of her responses to the Rorschach test concerning the feminine register. Thus it may be that Claudia and Lucy found the figurative materials of the TAT more supportive than the abstract character of the Rorschach test materials which induce regression, as if the figurative dimension gave glimpses of the potential for more flexibility in the heterogeneous functioning of Claudia and for greater rigidification in Lucy's functioning, with reference to Quinodoz (2002).

As stated above, in the projective tests we find two different modalities of abstraction of the difference between the sexes but, in this "need" for figurative materiality and this difficulty concerning abstract material with a regressive tendency, we also find echoes with the need for transformation as a drive realization through perception. With Lucy, the figurative material supports a freezing of drive activity and a narcissistic phantasy of the neuter gender, whereas with Claudia it seems to consolidate the difference between the sexes and compensate for identity-related and identificatory deficiencies. Of course, these observations based on two vignettes cannot be generalized, but we hope nonetheless that by presenting them we have been able to show the interest of differentiating between transsexualism and transgenderism and to highlight their respective relations to the difference between the sexes. Moreover, it is possible that issues of gender identity in relation to the difference between the sexes are more numerous and significant than the transsexual/transgender dichotomy suggests. In particular, it is very probable that far from being single, the transgender problem is in fact multiple. This pertinent distinction deserves to be investigated on a larger scale, but always with the psychoanalytic theoretical reference 
Marchand, J.-B., Pelladeau, E., Pommier, F. (2019). Transsexualism and transgenderism : unravelling sex and gender, and abstractions of the sexed body

[Transsexualisme et transgenderism : croisement-décroisement du sexe et du genre, et abstractions du corps sexué]. International Journal of Psychoanalysis, 100(2), 206-228. Doi: https://doi.org/10.1080/00207578.2019.1589377

which makes it possible to approach the underlying dimensions of these issues. This would provide us with a better understanding of these current phenomena which remain enigmatic today.

\section{References}

American Psychiatric Association (2013). Diagnostic and Statistical Manual of Mental Disorders: DSM-5. Arlington, VA: American Psychiatric Publishing.

American Psychological Association (2015). Guidelines for Psychological Practice with Transgender and Gender Nonconforming People. American Psychologist, 70(9):832864.

Bayle G (2012). Clivages. Moi et défenses. Paris: Presses Universitaires de France.

Benjamin H (1966). The transsexual phenomenon. New York: Julian Press.

Blanchard R (1989). The concept of autogynephilia and the typology of male gender dysphoria. J Nerv Ment Dis, 177: 616-623.

Brelet-Foulard F, Chabert C (2003). Nouveau manuel du TAT: approche psychanalytique. Paris: Dunod.

Castel PH (2003). La Métamorphose impensable: Essai sur le transsexualisme et l'identité personnelle. Paris: Gallimard.

Chabert C (1983). Le rorschach en clinique adulte. Paris: Dunod, 1997.

Chiland C (2003). Le transsexualisme. Paris: Presses Universitaires de France.

Dejours C (2001). Le corps d'abord. Paris: Payot.

Donnet JL, Green A (1973). L'enfant de ça. Psychanalyse d'un entretien: la psychose blanche. Paris: Les Editions de Minuit.

Green A (1973). The neuter gender. In: Life Narcissism, Death Narcissism, A. Weller (Trans.) London: Free Association Books, pp. 158- 169.

Kestemberg E (1999). "Astrid" ou homosexualité, identité, adolescence: quelques propositions hypothétiques. In L'adolescence à vif. Paris: Presses Universitaires de France, pp. 239-265.

Laplanche J (1986). La pulsion de mort dans la théorie de la pulsion sexuelle. In : La pulsion de mort. Paris: Presses Universitaires de France, 1986.

Laplanche J (2007). Gender, Sex, and the Sexual. In : Laplanche J (2011) Freud and the Sexual : Essays 2000-2006. pp. 159-201. 
Lemma A (2013). The body one has and the body one is: understanding the transsexual's need to be seen. Int J Psychoanal 94: 277-292.

Marchand J-B, Pelladeau E, Pommier F (2015). Du transsexualisme à la dysphorie de genre : regroupement ou amalgame. L'Evolution Psychiatrique 80(2), 331-348.

Marchand J-B (2016). Les tests projectifs à l'épreuve du sexe, du genre et des transformations corporelles. Dans M. Roques, C. Hurvy (dir.). Epreuves projectives et recherche en psychologie clinique. Paris : Editions In Press, pp. 93-112.

McDougall J (1982). Theaters of the mind: illusion and truth on the psychoanalytic stages. New York: Basic Books, 1985.

Money J, Hampson JG, Hampson JL (1955). Hermaphroditism: recommendations concerning assignment of sex, change of sex, and psychologic management. Bulletin of Johns Hopkins Hospital, 97:284-300.

Moulin V (2010). Evaluation des dysrégulations narcissiques et objectales et potentialités d'élaboration mentale chez les auteurs d'infractions sexuelles et violentes. Psychologie clinique et projective 16(1): 51-76.

Prince V (2005). Sex vs Gender. Int J Transgenderism, 8(4): 29-32.

Quinodoz D (2002). Termination of a fe/male transsexual patient's analysis: an example of general validity. Int J Psychoanal 83: 783-798.

Richelle J, Debroux P, De Noose L \& Malempré M (2009). Manuel du test de Rorschach. Approche formelle et psychodynamique. Paris: de Boeck.

Roques M (2014). Sexual masochism as an attempt at psychic reorganisation after paternal incest. IJP Open 98(1). [See : https://www.pep-web.org/document.php?id=ijpopen. 001.0098a]

Roussillon R (1999). Agonie, clivage et symbolisation. Paris: Presses Universitaires de France.

Schaeffer J (1997). Le refus du féminin. La sphinge et son âme en peine. Paris: PUF.

WPATH (2011). Standards of Care for the Health of Transsexual, Transgender, and GenderNonconforming People, Version 7. Int J Transgenderism, 13(4): 165-232. 